University of Nebraska - Lincoln

DigitalCommons@University of Nebraska - Lincoln

Publications from USDA-ARS / UNL Faculty

U.S. Department of Agriculture: Agricultural

Research Service, Lincoln, Nebraska

2009

Identification of various testicular cell populations in pubertal and adult cockerels

\author{
J. Mucksová \\ BIOPHARM
}

J. P. Brillard

Institut National de la Recherche Agronomique

J. Hejnar

Academy of Sciences of the Czech Republic

M. Poplštein

BIOPHARM

J. Kalina

BIOPHARM

See next page for additional authors

Follow this and additional works at: https://digitalcommons.unl.edu/usdaarsfacpub

Part of the Agricultural Science Commons

Mucksová, J.; Brillard, J. P.; Hejnar, J.; Poplštein, M.; Kalina, J.; Bakst, M.; Yan, H.; and Trefil, P., "Identification of various testicular cell populations in pubertal and adult cockerels" (2009). Publications from USDA-ARS / UNL Faculty. 616.

https://digitalcommons.unl.edu/usdaarsfacpub/616

This Article is brought to you for free and open access by the U.S. Department of Agriculture: Agricultural Research Service, Lincoln, Nebraska at DigitalCommons@University of Nebraska - Lincoln. It has been accepted for inclusion in Publications from USDA-ARS / UNL Faculty by an authorized administrator of DigitalCommons@University of Nebraska - Lincoln. 


\section{Authors}

J. Mucksová, J. P. Brillard, J. Hejnar, M. Poplštein, J. Kalina, M. Bakst, H. Yan, and P. Trefil 


\title{
Identification of various testicular cell populations in pubertal and adult cockerels
}

\author{
J. Mucksováa ${ }^{\text {, J.P. Brillard }}{ }^{\mathrm{b}}$, J. Hejnar ${ }^{\mathrm{c}}$, M. Poplštein ${ }^{\mathrm{a}}$, J. Kalina ${ }^{\mathrm{a}}$, \\ M. Bakst ${ }^{\mathrm{d}}$, H. Yan ${ }^{\mathrm{e}}$, P. Trefil ${ }^{\mathrm{a}, *}$ \\ a BIOPHARM, Research Institute of Biopharmacy and Veterinary Drugs, a.s., 25449 Jílové u Prahy, Czech Republic \\ b Station de Recherches Avicoles, Institut National de la Recherche Agronomique, Centre de Tours-Nouzilly, 37380 Monnaie, France \\ ' Institute of Molecular Genetics, Academy of Sciences of the Czech Republic, Vídeňská 1083, 14220 Prague 4, Czech Republic \\ d Animal Biotechnology and Biosciences Laboratory, Agricultural Research Service, US Department of Agriculture, \\ Beltsville, MD 20705, USA \\ e HIAVS (Hunan Institute of Animal and Veterinary Science), Quantang, Changsha 410131, Hunan, China
}

\section{A R T I C L E I N F O}

\section{Article history:}

Received 18 February 2008

Received in revised form 6 October 2008

Accepted 13 October 2008

Available online 31 October 2008

\section{Keywords:}

Spermatogonial cells

Spermatogenesis

Chicken

\begin{abstract}
A B S T R A C T
Precise identification of the male germinal stem cell population is important for their practical use in programs dedicated to the integration of exogenous genetic material in testicular tissues. In the present study, our aim was to identify germinal cell populations in the testes of pubertal and adult cockerels based on the detection of the nuclear DNA content by fluorescence-activated cell sorting (FACS) and on the expression of the Dazl and Stra8 genes in singlecell suspensions of testicular tissues. Cells with a tetraploid DNA content (4c) represent a small and equal fraction of the total germinal cell population in both pubertal and adult males. In contrast, the diploid (2c) and haploid (c) subpopulations differ significantly between ages as a consequence of different degrees of sexual maturation. A specific subpopulation of testicular cells, the side-scatter subpopulation of cells, or side population (SP), was identified at the junction between the haploid and diploid cell populations. The percentage of this cell subpopulation differs significantly in pubertal and adult cockerels, accounting for $4.1 \%$ and $1.3 \%$ of the total cell population, respectively. These four testicular cell populations were also tested for the expression of Dazl and Stra8 genes known to be expressed in premeiotic cells including stem spermatogonia. Both genes were expressed in SP, whereas the expression of either Dazl or Stra 8 genes was detected only in the $4 \mathrm{c}$ and in the $2 \mathrm{c}$ testicular
\end{abstract}

\footnotetext{
* Corresponding author. Tel.: +420 261395 234; fax: +420 241950503.

E-mail address: trefil@bri.cz (P. Trefil).
} 
cell subpopulations, respectively. The correlation between the cell ploidy and Dazl/Stra8 expression was the same at both male ages. We conclude that SP cells might represent a subpopulation of germinal cells enriched in stem spermatogonia, which can be of great importance for transgenesis in chicken.

(c) 2008 Elsevier B.V. All rights reserved.

\section{Introduction}

Fundamental knowledge of male germ line stem cell biology becomes to be urgently important in species with elaborated protocols of male germ cell transplantation. This technology promises to preserve the reproductive capacity of genetically valuable individuals and to produce transgenic animals via transplantation of isolated and genetically modified male germ line cells (Dobrinski, 2008). The precise identification of germinal stem cell populations, particularly that of spermatogonial stem cells, might be very helpful for efficient and reproducible transplantation and repopulation of recipient seminiferous epithelium. Over the past years, studies intended to provide some of the molecular and biochemical characteristics of stem spermatogonia in mammals have resulted in the development of workable techniques for the partial purification and transplantation of stem spermatogonia into recipient testes up to, in some cases, restoring functional spermatogenesis (Brinster and Avarbock, 1994; Russel and Brinster, 1996; Ogawa et al., 1997). In contrast to mammals, the identification of avian stem spermatogonia populations has become accessible only in fixed preparations of testes (Lin and Jones, 1992; Jones and Lin, 1993; Bakst et al., 2007) but remains to be established in fresh cell suspensions. This is an appreciable drawback of the chicken model, where the crude mix of testicular cells or partially purified testicular gonocytes can be productively transplanted into recipient testes or embryonal germinal ridges (Trefil et al., 2006; Kalina et al., 2007; Naito et al., 2007). The cytochemical characterization of chicken primordial germ cells (PGCs) and germline stem cell-like cells has been accomplished using the association of several markers including antibodies to SSEA-1 and EMA-1, lectins STA and DBA, antibodies to SSEA-3 and SSEA-4, as well as $\alpha 6$ and $\beta 1$ integrins (Jung et al., 2005, 2007). Studies in the adult mouse based on the screening of integrin receptors of laminin, a protein from the extracellular matrix, have demonstrated that it is possible to enrich testicular cell suspensions 166 -fold with isolated stem spermatogonia using a fluorescence-activated cell sorting analysis referring to light-scattering properties and expression of $\beta 1$ or $\alpha 6$ chains (Shinohara et al., 2000). It has now been established that $\alpha 6$ and $\beta 1$ integrins are also present in primordial germ cells both in the chicken and in the mouse embryo (Jung et al., 2005).

Among genes expressed at an early stage of spermatogenesis in the mouse, two stem cell marker genes, Stra 8 and $\alpha 6$-integrin, have been characterized. The Stra8 gene is expressed in spermatogonial cells (Ouland-Abdelghani et al., 1996) and the activity of its regulatory sequences has enabled purification of germinal stem cells (Giuili et al., 2002). Stra8 expression is clearly restricted to premeiotic germ cells (spermatogonia and possibly preleptotene spermatocytes) in the adult mouse testes, making this gene a putative candidate to identify premeiotic germ cells in other species (Lassalle et al., 2004). Regarding mouse $\alpha 6$-integrin, its expression was observed in fresh preparations of dispersed testicular cells enriched in stem spermatogonia isolated by flow cytometry (Lassalle et al., 2004). Additional observations by the same authors indicate that, at least in the mouse, several other genes including Dazl, c-Kit, Hsp70-2 and Crem $t$ can be proposed to identify germ cell populations prior to the first meiotic division. Meanwhile, Dazl and c-Kit genes are expressed only in side population (SP) and tetraploid cells, while the transcripts of $H s p 70-2$ and Crem $t$ genes are expressed at or after the spermatocyte stage.

Previous studies have revealed that SP cells can be identified on the basis of their dye-efflux properties at the boundary between $c$ and 2c DNA-containing cells after fluorescence staining of their nuclei with Hoechst 33342 (H342) and cell sorting (Lassalle et al., 2004; Bastos et al., 2005; Mays-Hoopes et al., 1995). In addition, SP cells have a small diameter and a low side scatter, which is also supportive for their identification. 
Several techniques have been proposed to purify germ cell populations in fresh preparations of mammalian testes including centrifugal elution (Meistrich et al., 1978), separation in discontinuous Percoll density gradients (Van Pelt et al., 1996; Izadyar et al., 2002), magnetic cell sorting (Van der Wee et al., 2001), lectins (Van Pelt et al., 1996) and monoclonal antibodies (Van Pelt et al., 2002). In contrast, techniques such as flow cytometry based on DNA content, light scatter parameters (Mays-Hoopes et al., 1995) and mitochondrial mass or activity (Suter et al., 1997) have proven useful mainly for sorting fixed germinal cell populations in the same species. Identification of spermatogonial stem cells for the transfer of exogenous cell populations is, indeed, difficult to resolve as it requires non-destructive techniques to appropriately identify, purify and reintroduce functional cell populations into recipient individuals. Among specificities shared by stem cells of various lineages and species, one refers to the relative inability of their nuclei to take up supravital fluorescent probes such as bis-benzimide, more commonly referred (Goodell et al., 1996) to as H342. In the case of germinal tissues, this DNA-binding probe was used to identify SP cells among mouse testicular cells highly enriched in stem spermatogonia after inhibition of H33342 efflux by treatment with BCRP1 inhibitor Ko143 (Lassalle et al., 2004; Bastos et al., 2005). Such observations contradict another study also performed in the mouse in which the transplantation of SP cells derived from cryptorchid males was unsuccessful at colonizing recipient testes (Kubota et al., 2003). However, it has since been established that SP issued from cryptorchid males are devoid of stem spermatogonia (Bastos et al., 2005).

In the present study, an attempt was made to identify and partly purify dispersed germinal cell populations in the testes of pubertal and adult chickens in order to access viable stem spermatogonia populations for further studies of gene transfer through the male lineage. The identification of testicular cell populations was performed after differential staining and fluorescence-activated cell sorting (FACS) of single-cell suspensions of testicular tissue followed by RNA extraction and RT-PCR of gene markers for a precise identification of each germinal cell category.

\section{Materials and methods}

\subsection{Experimental birds}

A total of five pubertal (12 weeks of age) and five adult (28 weeks of age) inbred White Leghorn cockerels (WL; genotype II) issued from the Institute of Molecular Genetics (Academy of Sciences of the Czech Republic, Prague) were trained for semen collection and then used as semen donors. Males were kept in individual cages $\left(4200 \mathrm{~cm}^{2}\right)$ fitted with perches under standard husbandry conditions with photoperiod adjusted at 12L:12D. Feed and water were provided ad libitum. All experiments were performed in accordance with the CZ legal requirements for animal welfare (Acts Nos. 246/199, $162 / 1993$ and 193/1994).

\subsection{Preparation of single-cell suspension of testicular tissue}

Pubertal and adult animals were humanely sacrificed and their testes removed. For each testis, the tunica albuginea was excised and the seminiferous tubules isolated from interstitial tissue as described by Lassalle et al. (2004). Testicular preparations were at first subjected to enzymatic digestion (50 min at $\left.34^{\circ} \mathrm{C}\right)$ using Type I collagenase diluted in PBS $(100 \mathrm{U} / \mathrm{ml}$; Biochrom AG, Germany) supplemented with $1.2 \mathrm{mM} \mathrm{MgSO}_{4}\left(7 \times \mathrm{H}_{2} \mathrm{O}\right), 1.3 \mathrm{mM} \mathrm{CaCl}_{2}\left(2 \times \mathrm{H}_{2} \mathrm{O}\right), 6.6 \mathrm{mM}$ sodium pyruvate and $2 \mathrm{mM}$ glutamine (final $\mathrm{pH}$ 7.2). Seminiferous tubule fragments were then isolated by two successive filtrations through a $40 \mu \mathrm{m}$ nylon mesh to remove cell clumps, washed in PBS, centrifuged at $400 \times \mathrm{g}$ for $5 \mathrm{~min}$, and the resulting pellet was resuspended in PBS supplemented with $1 \%$ fetal bovine serum.

\subsection{Flow cytometry}

The identification of several testicular cell populations was performed on the basis of their DNA content using testicular cell suspensions stained with $\mathrm{H} 342$ diluted in PBS ( 90 min at $37^{\circ} \mathrm{C}$ ) at a final concentration of $5 \mu \mathrm{M}$. The analyses of cell cycle in these cells were performed from cell suspensions stained for 30 min with H342 diluted in PBS at a final concentration of $10 \mu \mathrm{M}$ (room temperature). 
Propidium iodide (PI) at a concentration of $5 \mu \mathrm{g} / \mathrm{ml}$ was used as counter stain to exclude non-viable cells (red fluorescence of their nuclei). Flow cytometry analyses were performed with a FACSVantage SE flow cytometer (Becton Dickinson, USA) equipped with a two-stream argon-helium laser (Coherent Enterprise EE, Orsay, France). The various categories of cells stained by $\mathrm{H} 342$ were excited by a UV laser adjusted to $50 \mathrm{mV}$ using a combination of $485 \mathrm{~nm}$ long-pass and $505 \mathrm{~nm}$ short-pass filters in front of the first detector, while cell populations stained with PI were detected with a $682 \mathrm{~nm} / 22 \mathrm{~nm}$ bandpass filter in front of the second detector. Fluorescence intensity was measured as a linear scale. Some cell types display shift of fluorescence into red light after staining with H342. Among the various cell categories, the SP population was sorted on the basis of three additive criteria: 2c-DNA content, low side scatter, and small nuclear diameter (Bakst et al., 2007). Dead cells were not visible because they were outside the frame of the diagram. Control of the elimination of dead cells was made possible by using PI staining (excitation wavelength: $488 \mathrm{~nm}$ ).

\subsection{RNA extraction and RT-PCR of genes Stra8, Dazl and $\beta$-actin}

A total of $10^{5} \mathrm{H} 342$ positive cells were sorted and suspended into a solution of Rneasy Plus Mini Kit for RNA purification (Qiagen). Total RNA was then subjected to reverse transcription with a first strand cDNA synthesis kit (Fermentas). Primers developed for detection of the other genes were as follows: Stra8 (forward 5'-tatccatagagtccttcagcc-3', reverse 5'-cttcagaaagctcttgccaga-3'), $\beta$ actin (forward 5'-acaatggctccggtatgtgca-3', reverse $5^{\prime}$-gttcaggggagcctctgtgag-3'), and Dazl gene (forward $5^{\prime}$-gcttgcatgcttttcctgct-3', reverse $5^{\prime}$-tgcgtcacaaagttaggca-3'), these primers for Dazl were prepared as described by Van de Lavoir et al. (2006). For all these genes, PCR conditions were as follows: $94{ }^{\circ} \mathrm{C}$ for $1 \mathrm{~min}, 36 \mathrm{cycles}$ of $94^{\circ} \mathrm{C}$ for $30 \mathrm{~s}, 60^{\circ} \mathrm{C}$ for $30 \mathrm{~s}$, and $72^{\circ} \mathrm{C}$ for $30 \mathrm{~s}$. Products of PCR reactions were resolved in a $1 \% \mathrm{TAE}$-agarose gel with ethidium bromide $(0.5 \mu \mathrm{g} / \mathrm{ml})$.

\subsection{Statistical analysis}

Comparisons between the proportions of testicular cells involved in spermatogenesis at the prepubertal and adult stages were performed by analysis of variance and $t$-test after arcsine transformation (Microsoft Excel 2000). Percentage data were arcsine transformed. Data from the present study are shown as the mean \pm SEM. A value of $P<0.05$ was accepted as statistically significant.

\section{Results}

\subsection{Identification of cell populations based on DNA content}

Flow cytometric analyses of single-cell preparations subjected to fluorescent probes $\mathrm{H} 342$ and PI resulted in the identification of five different subpopulations of cells classified according to the emission of more or less marked red or blue fluorescence of their nuclei (Fig. 1). Cells with a nucleus intensively stained in red were classified as necrotic and, as such, discarded from further analyses. The remaining four cellular categories expressed various intensities of blue fluorescence. As such, they were classified as viable and therefore subjected to flow cytometric analyses (Fig. 1A). Within each group of males (pubertal or sexually mature), the histogram derived from pre-cited analyses reflected nuclear surface characteristics in each cellular category, thus allowing discrimination between these cells on the basis of their DNA content (c, 2c or 4c; Fig. 1B). Cells with a tetraploid (4c) DNA content represented $8.4 \%$ and $7.9 \%$ of the total cell population analysed in pubertal and sexually mature males, respectively. These cells located in the upper region of Fig. 1A were considered as reflecting the DNA content of germinal cell nuclei characteristic of the first meiotic prophase. In contrast, cells present in the intermediate region of the figure were identified as having a diploid (2c) DNA content, itself characteristic of germinal nuclei having undertaken mitosis II, i.e. Type-II spermatocytes. Cells with a haploid nuclear DNA content (c) were identified as having reached spermiogenesis and, as such, identified as round spermatids (see lower region of Fig. 1 ). In contrast, significant differences $(P<0.05)$ were observed in the percentages of cells expressing haploid or diploid nuclear DNA content between the populations of cells issued from pubertal compared to adult males (haploid: $25.5 \%$ vs. $54.6 \%$; 
(A) Adult

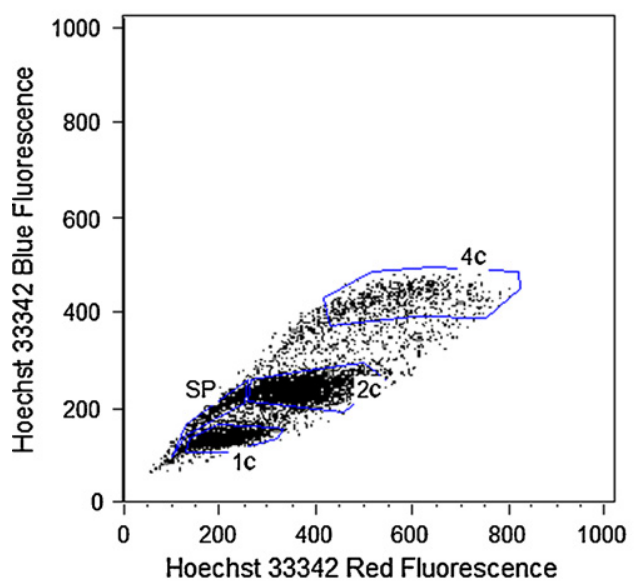

(B) Adult

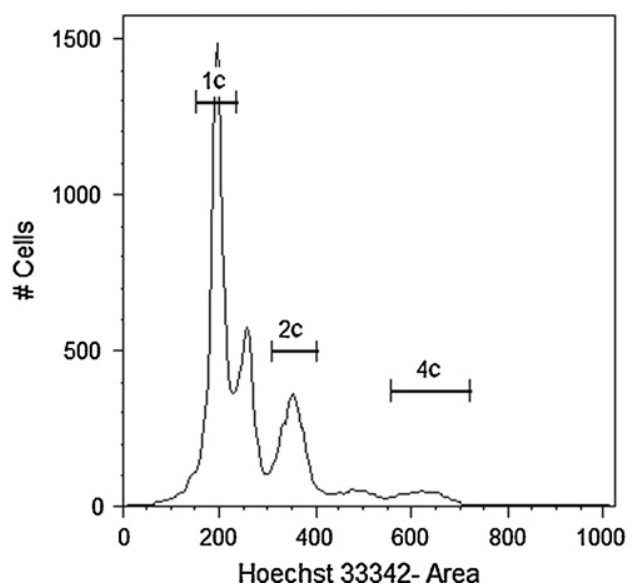

Pubertal

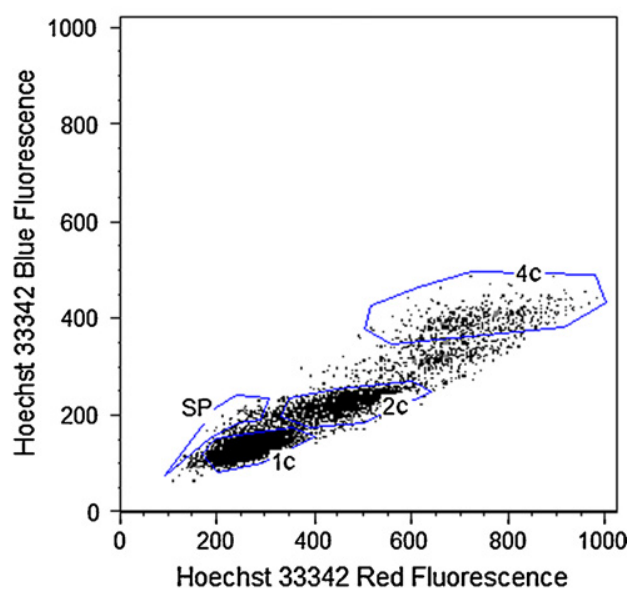

Pubertal

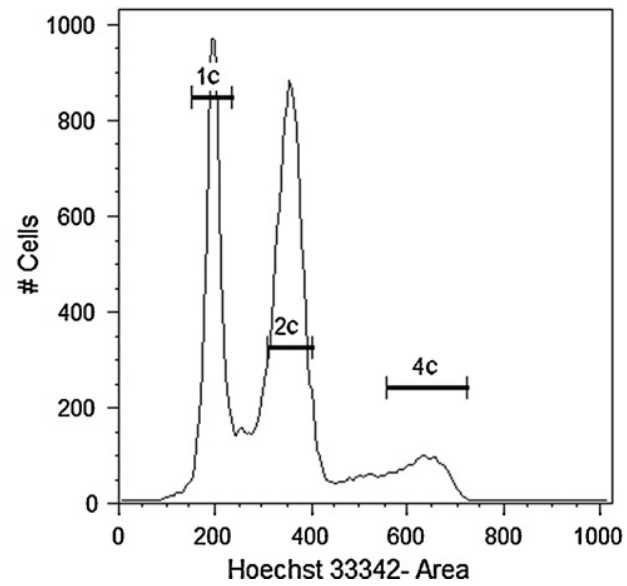

Fig. 1. (A) Flow cytometric analysis of pubertal and adult chicken testicular cells stained with Hoechst 33342 and PI fluorescence. Visible populations of pubertal and adult tetraploid testicular cells, premeiotic spermatocytes I (4c), diploid testicular cells (2c), haploid spermatids (c) and specific population of testicular cells referred to as SP cells. (B) Dual-parameter flow cytometric analysis of pubertal and adult testicular cell cycle stained with $\mathrm{H} 342$ and PI (propidium iodide) fluorescence. The population of adult and pubertal testicular cells consisted of haploid (c) testicular cells, diploid (2c) cells in G1 phase, tetraploid cells and premeiotic spermatocytes I (4c) in G2/M phase of the cell cycle. The small peak between the 1c and 2c cell populations did not reveal SP cell population. The content of this peak remains undefined.

diploid: $44.7 \%$ vs. $18.9 \%)(P<0.05$ in both cases; Table 1$)$. Finally, a specific subpopulation of testicular cells expressing blue fluorescence with low intensity was identified at the junction between $\mathrm{c}$ and $2 \mathrm{c}$ DNA-containing cell subpopulations. Such cells were referred to as a side-scatter subpopulation (SP). They accounted for $4.1 \%$ of the total cell population analysed in pubertal males compared to only $1.3 \%$ in adult males $(P>0.05)$.

\subsection{RT-PCR analysis of markers in flow-sorted cellular subpopulations}

The four subpopulations of FACS-selected testicular cells were tested for the expression of Dazl and Stra8 genes in preparations from both categories of cockerels. These two genes were expressed 
Table 1

Transformed data of percentage of cells with haploid (N), diploid (2N) or tetraploid (4N) nuclear DNA content and side population (SP) among viable cells from single-cell suspensions of pubertal and adult testicular tissues in chicken.

\begin{tabular}{lllll}
\hline & $\mathrm{c}$ & 2c & 4c & SP \\
\hline Adult & $0.578(0.051)^{*}$ & $0.19(0.034)^{*}$ & $0.084(0.036)$ & $0.013(0.002)^{*}$ \\
Pubertal & $0.258(0.028)$ & $0.466(0.08)$ & $0.079(0.013)$ & $0.041(0.006)$ \\
\hline
\end{tabular}

Data are expressed as mean (standard deviation).

$P<0.05$.

(A)
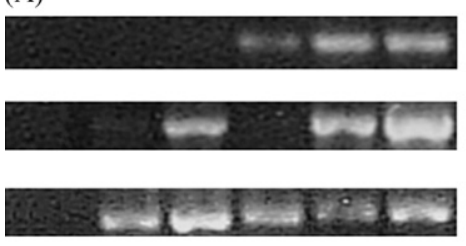

$\mathrm{NC} \quad \mathrm{c} \quad 4 \mathrm{c} \quad 2 \mathrm{c} \quad \mathrm{SP} \quad \mathrm{T}$
(B)

\section{Stra $8(371 \mathrm{bp})$}

Dazl (563 bp)

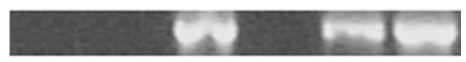

Actin (302 bp)

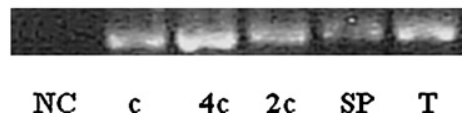

Fig. 2. Expression of differentiation markers in the sorted testicular cell subpopulations from pubertal(A) and adult (B) cockerels. RNAs from the whole testes (T) together with sorted haploid (c), diploid (2c), tetraploid (4c) and SP cell populations were analysed via RT-PCR. RT-PCR was performed for the Dazl (30 cycles), Stra8 (30 cycles), and $\beta$-actin (30 cycles) genes. Control (NC) (RNA from the whole testicular tissue without reverse transcription).

in the SP cell population. Among cell populations characterized by various DNA contents (c, 2c, 4c), the Dazl gene was expressed only in the 4c cells and Stra8 gene only in the 2c cells (Fig. 2). Within a given subpopulation of cells, the expression of Dazl and Stra8 genes had similar patterns in pubertal and adult males. Detection of the housekeeping $\beta$-actin control gene confirmed the correct course of RT-PCR.

\section{Discussion}

In this study, a dual experimental approach was used to characterize and sort testicular cell populations from single-cell suspensions of pubertal and adult testicular tissues in the chicken. The general procedure, which combines FACS with marker genes, has already been successfully attempted to identify germinal cell populations and partly purify an SP phenotype enriched in stem spermatogonia in the mouse (Lassalle et al., 2004; Bastos et al., 2005). One characteristic of the FACS approach is based on repeated observations that germinal and somatic stem cell populations express low or no fluorescence when subjected to supravital fluorescent probes such as H342 or Rhodamine 123 (Spangrude and Johnson, 1990; Lassalle et al., 2004; Lo et al., 2005). The fluorescence of cells stained with H342 is a nonlinear process that shows an overall decrease in intensity with increased dye uptake, and spectral shift to the red (Petersen et al., 2004). The efflux of these probes from stem cell nuclei has been attributed to the existence of a p-glycoprotein pump activated by $\operatorname{Brcp} 1$, a gene which has been suggested to provide protection against cytotoxic substrates at least in hematopoietic cells (Zhou et al., 2002). Controlling the elimination of dead cells from the preparations is technically feasible by sorting these cells following PI nuclear staining. In the present study, the SP phenotype was present in testicular cell suspensions from both pubertal and adult males, but the percentage of cells carrying this phenotype reached $4.1 \%$ of the total population analysed in pubertal compared to only $1.3 \%$ in adult males $(P<0.05)$. In contrast, haploid cells, specific of spermiogenesis, accounted for $25.5 \%$ in pubertal and $54.6 \%$ in adult males. In both cases, the differences between the two types of males were significant $(P<0.05)$. Such differences are themselves the consequence of differences in testicular development between the two types of males, those having reached the pubertal stage being several weeks from sexual maturity, a period at which seminiferous tubules contain large proportions of haploid cells (round and elongated spermatids, testicular spermatozoa) characteristic of spermiogenesis (de Reviers, 1971). In the chicken, the pubertal stage, itself defined as the stage of development during 
which an animal first becomes capable of reproducing sexually (Plant, 1999), has been histologically characterized by the presence of the first testicular spermatozoa present in seminiferous tubule sections (de Reviers, 1971). This stage can be observed in testes $>1 \mathrm{~g}$ from 12-week-old males subjected to a photostimulatory photoperiod, a situation similar to experimental conditions used in the present study for this group of males.

Based on observations performed in the mouse, we used a combination of two genes, Dazl and Stra8, as putative candidates to identify germinal cell subpopulations in pubertal and adult chickens. In the mouse, the Dazl gene is expressed in SP and 4c cells, while Stra8 is observed only at a premeiotic stage which includes 2c (spermatogonia) and 4c (Type-I spermatocytes at preleptotene stage) cells. In the present study, the expression of the Dazl and Stra8 genes was analysed in germ cell subpopulations sorted on the basis of their DNA content. For a given category of cells, both genes were expressed similarly in pubertal and adult males, but their expression was highly different between germinal cells depending on their position in the process of spermatogenesis. For example, neither of these two genes was expressed in c cells while Stra8 was expressed only in 2c and Dazl in 4c cells. Interestingly, both types of genes were strongly expressed in SP cells while Dazl was expressed only in germ cells having reached the preleptotene/leptotene (4c) stage. These observations, similar to those previously reported in the mouse (Lassalle et al., 2004), strongly suggest that the chicken SP population isolated from pubertal and adult testes has been enriched with stem spermatogonia. In adult males, the fraction of SP cells recovered from single-cell suspensions accounted for only $1.3 \%$ of the total germinal cell population, a percentage itself similar to the percentage of SP cells recovered from dispersed germinal cell populations from adult mouse testes (Lassalle et al., 2004).

\section{Conclusion}

In conclusion, this study performed in the chicken reports for the first time the existence of SP cells present in different proportions among single-cell suspensions of pubertal and adult testicular tissues. Such cells express the Dazl and Stra8 genes in a manner similar to mouse SP cells, themselves recognized as a subpopulation of germinal cells highly enriched in stem spermatogonia. Additional studies of cell transfer into recipient males are now necessary to test the hypothesis that SP cell populations, as defined here, may provide enriched cell populations of stem spermatogonia capable of colonizing recipient seminiferous tubules in larger proportions than in our previous observations (Trefil et al., 2006).

\section{Acknowledgements}

The authors would like to thank Mr. Zdenek Cimburek (Institute of Microbiology, Academy of Sciences of the Czech Republic) for FACS analysis. This work was supported by grants Nos. ME 908 and 1P05ME722 from the Grant Agency of the Ministry of Education (PT), Youth and Sports and grant No. $523 / 07 / 1171$ awarded by the Grant Agency of the Czech Republic (JH).

\section{References}

Bakst, M.R., Akuffo, V., Trefil, P., Brillard, J.P., 2007. Morphological and histochemical characterization of the seminiferous epithelial and Leydig cells of the turkey. Anim. Reprod. Sci. 97, 303-313.

Bastos, H., Lassalle, B., Chicheportiche, A., Riou, L., Testart, J., Allemand, I., Fouchet, P., 2005. Flow cytometric characterisation of viable meiotic and postmeiotic cells by Hoechst 33342 in mouse spermatogenesis. Cytometry 65 A, 40-49.

Brinster, R.L., Avarbock, M.R., 1994. Germ line transmission of donor haplotype follow in spermatogonial transplantation. PNAS 91, 11303-11307.

Dobrinski, I., 2008. Male germ cell transplantation. Reprod. Domest. Anim. 43 (Suppl. 2), 288-294.

Giuili, G., Tomljenovic, A., Labrecque, N., Ouland-Abdelghani, M., Rassoulzadegan, M., Cuzin, F., 2002. Murine spermatogonial stem cells: target transgene expression and purification in an active state. EMBO Rep. 3, 753-759.

Goodell, M.A., Browse, K., Paradis, G., Konner, A.S., Mulligamm, R.C., 1996. Isolation and functional properties of murine hematopoietic stem cells that are replicating in vivo. J. Exp. Med. 183, 1797-1806.

Izadyar, F., Spierenberg, G.T., Creemers, L.B., den Ouden, K., de Rooij, D.G., 2002. Isolation and purification of type A spermatogonia from the bovine testis. Reproduction 124, 85-94.

Jones, R.C., Lin, M., 1993. Spermatogenesis in birds. Oxf. Rev. Reprod. Biol. 15, 233-264. 
Jung, J.G., Kim, D.K., Park, T.S., Lee, S.D., Lim, J.M., Han, J.Y., 2005. Development of novel markers for the characterisation of chicken primordial germ cells. Stem Cells 23, 689-698.

Jung, J.G., Lee, Y.M., Park, T.S., Park, S.H., Lim, J.M., Han, J.Y., 2007. Identification, culture, and characterization of germline stem cell-like cells in chicken testes. Biol. Reprod. 76, 173-182.

Kalina, J., Šenigl, F., Mičáková, A., Mucksová, J., Blažková, J., Yan, H., Poplštein, M., Hejnar, J., Trefil, P., 2007. Retrovirus-mediated in vitro gene transfer into chicken male germ line cells. Reproduction 134, 445-453.

Kubota, H., Avarbock, M.R., Brinster, R.L., 2003. Spermatogonial stem cells share some, but not all, phenotypic and functional characteristics with other stem cells. PNAS 100, 6487-6492.

Lassalle, B., Bastos, H., Louis, J.P., Riou, L., Dutrillaux, B., Fouchet, P., Allemand, I., 2004. Side population cells in adult mouse testis express Bcrp1 gene and are enriched in spermatogonia and germinal cell cells. Development 131, 479-487.

Lin, M., Jones, R.C., 1992. Renewal and proliferation of spermatogonia during spermatogenesis in the Japanese quail Coturnix coturnix japonica. Cell Tissue Res. 267, 591-601.

Lo, K.C., Brugh, V.M., Parker, M., Lamb, D.J., 2005. Isolation and enrichment of murine spermatogonial stem cells using rhodamine 123 mitochondrial dye. Biol. Reprod. 72, 767-771.

Mays-Hoopes, L.L., Bolen, J., Riggs, A.D., Singer-Sam, J., 1995. Preparation of spermatogonial, spermatocytes and round spermatids for analysis of gene expression using fluorescence-activated cell sorting. Biol. Reprod. 53, 1003-1011.

Meistrich, M.L., Hunter, N.R., Suzuki, N., Trostle, P.K., Withers, H.R., 1978. Gradual regeneration of mouse testicular stem cells after exposure to ionizing radiation. Radiat. Res. 74, 349-362.

Naito, M., Minematsu, T., Harumi, T., Kuwana, T., 2007. Testicular and ovarian gonocytes from 20-day incubated chicken embryos contribute to germline lineage after transfer into bloodstream of recipient embryos. Reproduction 134, 577-584.

Ogawa, T., Aréchag, J.M., Avarbock, M.R., Brinster, R.L., 1997. Transplantation of testis germinal cells into mouse seminiferous tubules. Int. J. Dev. Biol. 41, 111-122.

Ouland-Abdelghani, M., Bouillet, P., Décimo, D., Gansmuller, A., Heyberger, S., Dollé, P., Bronner, S., Lutz, Y., Chambon, P., 1996. Characterization of a premeiotic germ cell-specific cytoplasmic protein encode by Stra8, a novel retinoic acid-responsive gene. J. Cell Biol. 135, 469-477.

Petersen, T.W., Ibrahim, S.F., Diercks, A.H., van den Engh, G., 2004. Chromatic shifts in the fluorescence emitted by murine thymocytes stained with Hoechst 33342. Cytometry A 60, 173-181.

Plant, T.M., 1999. Puberty in non human primates. In: Knobil, E., Neill, J.D. (Eds.), Encyclopedia of Reproduction (Pro-Z). vol. 4. Academic press, pp. 135-142.

de Reviers, M., 1971. Le dévelopment testiculaire chez le coq II. Morphologie des tubes séminifères et établissement de la spermatogenèse. Ann. Biol. Anim. Biophys. Biochem. 11, 531-546 (in French).

Russel, L.D., BrinsterF R.L., 1996. Ultrastructural observations of spermatogenesis following transplantation of rat testis cells into mouse seminiferous tubules. J. Androl. 17, 615-627.

Shinohara, T., Orwig, K.E., Avarbock, M.R., Brinster, R.L., 2000. Spermatogonial stem cell enrichment by multiparameter selection of mouse testis cells. PNAS 97, 8346-8351.

Spangrude, G.J., Johnson, G.R., 1990. Resting and activated subsets of mouse multipotent hemopoietic stem cells. PNAS 84, 7433-7437.

Suter, L., Koch, E., Bechter, R., Bobadilla, M., 1997. Three-parameters flow cytometric analysis of rat spermatogenesis. Cytometry 27, 161-168.

Trefil, P., Mičáková, A., Mucksová, J., Hejnar, J., Poplštein, M., Bakst, M.R., Kalina, J., Brillard, J.P., 2006. Restoration of spermatogenesis and male fertility by transplantation of dispersed testicular cells in the chicken. Biol. Reprod. 75, 575-581.

Van de Lavoir, M.C., Diamond, J.H., Leighton, P.A., Mather-Love, C., Heyer, B.S., Bradshaw, R., Kerchner, A., Hooj, L.T., Gessaro, T.M., Swanberg, S.E., Delany, M.E., Etches, R.J., 2006. Germline transmission of genetically modified primordial germ cells. Nature $441,766-769$.

Van der Wee, K.S., Johnson, E.W., Dirami, G., Dym, T.M., Hofmann, M.C., 2001. Immunomagnetic isolation and long term culture of mouse type A spermatogonia. J. Androl. 22, 696-704.

Van Pelt, A.M., Morena, A.R., van Dissel-Emiliani, F.M., Boitani, C., Gaemers, I.C., de Rooij, D.G., Stefanini, M., 1996. Isolation of the synchronized A spermatogonia from adult vitamin A-deficient rat testes. Biol. Reprod. 55, 439-444.

Van Pelt, A.M., Roepers-Gajadien, H.L., Gademan, I.S., Creemers, L.B., de Rooij, D.G., van Dissel-Emiliani, F.M., 2002. Establishment of cell lines with rat spermatogonial stem cell characteristics. Endocrinology 143, 1845-1850.

Zhou, S., Morris, J.J., Barnes, Y., Lan, L., Schuetz, J.D., Sorrentino, B.P., 2002. Bcrp1 gene expression is required for normal numbers of side population stem cells in mice, and confers relative protection to mitoxantrone in hematopoietic cells in vivo. PNAS 99, 12339-12344. 